\title{
Internationalizing Teacher Education: What is the Erasmus Exchange Program's Contribution in Turkey?
}

\author{
Ezgi Gürel $^{1} \&$ Berna Aslan ${ }^{2}$ \\ ${ }^{1}$ International Relations Office, Afyon Kocatepe University, Afyonkarahisar, Turkey \\ ${ }^{2}$ Faculty of Educational Sciences, Ankara University, Ankara, Turkey \\ Correspondence: International Relations Office, Afyon Kocatepe University, ANS Campus, Afyonkarahisar, \\ Turkey. Tel: 90-272-218-1566. E-mail: egurel@ aku.edu.tr
}

\author{
Received: January 7, 2022 \\ Accepted: February 8, $2022 \quad$ Online Published: February 18, 2022 \\ doi:10.5539/hes.v12n1p131 \\ URL: https://doi.org/10.5539/hes.v12n1p131
}

\begin{abstract}
This paper analyzes the effects of internationalization seen through the Erasmus program in teacher education programs. The study's importance is that teacher training is generally funded for local environments by state systems; subsequently teacher candidates have less opportunity for global curricula. One of Turkey's most vital tools for internationalization is the Erasmus exchange program. Thus, this study focuses on interviews with teacher candidates having international exchange experience and teacher educators involved as program coordinators in their own education faculties. Twelve participants from different teacher training areas at diverse universities were interviewed. The research findings reveal that students' social and cultural skills developed more than their academic competencies and professional teaching skills. Although the program makes an essential contribution to internationalization on both individual and institutional bases; we reveal that course selection problems, difficulties in academic recognition processes, foreign language problems, and the lack of possibility of taking the practicum course abroad have adverse effects on the process. This research addresses knowledge gaps in internationalization policy as teacher candidates, and teacher educators' voices are not heard in such initiatives. The study suggests that education faculties need solid foundations for internationalization efforts.
\end{abstract}

Keywords: internationalization, teacher candidates, Erasmus exchange, student mobility, teacher educators

\section{Introduction}

Various academic environments have discussed the need for internationalization in teacher education and its positive effects on teacher candidates (Abraham \& von Brömssen, 2018; Acedo, 2012; Garii, 2008; Quezada, 2010; Sieber \& Mantel, 2012). In this respect, Kissock and Richardson (2010) emphasize a primary concern of the internationalization in teacher training in this way:

It is time that we heed the extensive literature calling on us to internationalize our teacher education and bring a global perspective to education decision making to prepare globally-minded professionals who can effectively teach any child from, or living in, any part of the world (p.89).

The positive effects of this internationalization are primarily stated in the literature as enabling teacher candidates intercultural development and their adaptation to this situation in their future lives as teachers, development of the ability to cope with complex situations, global open-mindedness, intellectual growth, and personal development (Mahon, 2010; Walters, Garii, \& Walters, 2009).

Despite these positive effects of internationalization taken into consideration, the education systems and implementations, including teacher training, are administered, organized, and financed by the state (Olmos \& Torres, 2009). This situation reveals that teacher education has a mission to prepare candidates for the teaching they will conduct locally. A similar case is in teacher education in Turkey. In item 43 of the Basic National Education Law no. 1739, the Ministry of National Education (MoNE) uses the following expressions: "Teaching is a specialized profession, which assumes the duties of state education and the administration of these" (MoNE, 2011). From this viewpoint, teacher training is an institutional process for reproducing national education systems. These programs have a mission to make teachers fit for specific national contexts which is firmly managed on a regional basis. Therefore, states shape teacher training traditionally on a national origin. Complex 
historical, political, social, cultural, and educational factors mainly affect the characteristic features of teacher training programs in a national context. The focus is always on the nation's educational needs. In short, teacher education fulfils employment areas whose resources are managed locally and it has different functions from various other higher education programs, such as finance, trade, industry, or technology (Leutwyler, Popov, \& Wolhuter, 2017). Accordingly, it is expected that teacher candidates complete their education in local environments. However, this is a narrow-minded viewpoint for many scholars (Larsen, 2016; Schneider, 2004; Walters et al., 2009).

While the government policies occupy an essential place in teacher education programs, the developments that occurred through globalization have also affected teacher training and complicated this process (Sieber \& Mantel, 2012). On the one hand, the increasing need for internationalization, and on the other, the traditional dependence on powerful local contexts, is a conflicting situation for teacher training to be found. It is for this reason that while numerous researchers in the field of teacher education recommend that teacher candidates gain experience abroad in terms of internationalization of programs (Kissock \& Richardson, 2010; Mahon \& Cushner, 2002; Vorkapic, 2016; Weidman, Jacob, \& Casebeer, 2014; White, 2016), only very few teacher education programs have made an effort to integrate a global program into their teacher education curricula. In any case, the internationalization of teacher education is essential in increasing the mobility of teacher candidates who receive pre-service and in-service training; many teacher candidates who complete their training seek opportunities abroad to further their experience and consolidate the internationalization requirements and diversification efforts of local schools (Weidman et al., 2014).

Internationalization is realized in various ways in teacher education programs globally. Nevertheless, Turkey's essential mean of internationalization is the Erasmus (European Action Scheme for the Mobility of University Students) program. The program's characteristic features are supporting regional mobility among European nations, giving support for a temporary period of learning abroad, encouraging mobility and collaboration between higher education institutions, and enabling the integration of higher education curricula (Maiworm, 2001). Considering the 33-year history of the Erasmus program, we see that various studies have been conducted on the national and regional effects of the program (Aslan \& Jacobs, 2014; Dinçer, Aslan, \& Bayraktar, 2017; Jacobone \& Morro, 2015; Llurda, Gallego-Balsà, Barahona, \& Martin-Rubió, 2016; Mizikaci \& Arslan, 2019; Papatsiba, 2006; Szymanska, 2014; Teichler, 2004). However, no studies in the literature scrutinize the effects of the Erasmus program on teacher education with three different sample groups (incoming students, outgoing students, and coordinators). Additionally, this study presents how this program can be beneficial for teacher candidates and what changes should be made to improve the current efforts for the internationalization of teacher education in Turkey. Hence, the research question designed to this end is as follows:

- What is the contribution of the Erasmus exchange program to teacher training in Turkey in terms of internationalization?

\section{Literature Review}

\subsection{Interaction between Globalization and Internationalization in Teacher Training: Definitional Issues}

Globalization is defined as the flow of knowledge, ideas, resources, and people beyond political boundaries due to economic and technological developments (Castles 2004; Luke and Carrington 2001, as cited in Harper and Dunkerly, 2013). It creates increasing interconnectedness between nation-states and inevitably, education systems are also affected and entrusted to produce learners who are equipped with specific knowledge and skills that can feed into the global economy of the 21st century (Nazeer-Ikeda, 2014). This situation can also be understood from the words of Weidman et al. (2014): "The worldwide quality of education is influenced not only by the educational policies of individual nations but more importantly by how these nations can work together to provide quality education to as many people as possible." In this context, several researchers in the literature (Goodwin, 2010; Quezada, 2010; Zeichner, 2010; Zhao, 2010) defend the need to integrate global education into teacher training programs so that teacher candidates can respond to present-day conditions, understand learners' needs in classrooms, and overcome problems expressed in a global context.

Internationalization is defined as "the process of integrating an international, intercultural or global dimension into the purpose, functions or delivery of post-secondary education" (Knight, 2004, p.11) and it is highly mentioned in policy documents of universities. This trend toward internationalization is considered both as a reason and a result of the globalization process in education and realized in different forms as international curricula, the growth of international service, international internship experiences, cross-border initiatives, and the increasing use of English as a Medium of Instruction (EMI) in higher education outside the Anglo-Speaking world (Larsen, 2016). In this regard, it is argued that internationalization in higher education institutions, 
including teacher training programs, can respond to the need for globalization (Altbach, 2004), or internationalization can have a dialectic relationship with globalization (Marginson \& Van Der Wende, 2009).

Internationalization, however, is a definition that creates different perceptions in different people. In the past twenty or thirty years, the international dimension of higher education institutions has caused the concept of "internationalization" to become a broad concept used for all situations worldwide with intercultural, global, and international dimensions. For many people, "internationalization" means academic mobility for students and personnel, international partnerships and projects, and new international academic programs and research innovations (Knight, 2012). Motivations for internationalization consist of universities' gaining a commercial advantage, their desire to enrich their curricula with international content, and other innovations. International cooperation agreements, international student programs, and notable innovations such as English as the language of instruction in higher education programs form the basis of these motivations (Altbach \& Knight, 2007). In connection with all these motivations; cooperating with other universities abroad, developing the overseas scientific relationships of academicians within universities, assisting academicians on scientific visits, coordinating the implementation of international cooperation programs such as Erasmus for students and personnel, and reinforcing the international image specific to the university itself are accepted as part of internationalization in higher education (Szymanska, 2014). In this sense, internationalization has become vital for many programs within higher education institutions nowadays. Globally, universities follow specific indicators of internationalization. These indicators are the number of international students, the international history of academicians employed at the university, the university's position in the global ranking, and therefore the university's places in the quality processes (Brandenburg \& Federkeil, 2007; Scott, 2009).

Recently, the importance of internationalization in teacher education has increased due to two situations. These are the increasing importance of internationalization in view of the globalization of the world and the expanding consciousness of teachers concerning being one of the most important factors for providing high-quality education for everyone (Sieber \& Mantel, 2012). Within the scope of this consciousness, as well as being seen as a factor in striving to keep students at school, teachers should ensure that students acquire the necessary skills to participate in social, economic, and political life; additionally, teachers should alert everyone to the necessity of good quality education, liberate students' intellects, and contribute to peace, sustainable development and equality (Teachers for EFA, 2011). To train teachers in line with this characterization, teacher candidates should possess the pedagogical approaches (flexibility, adaptability, autonomy, creativity, and ability to think reflectively) required to cope with phenomena that are frequently encountered in society nowadays, such as migration and multicultural communities, intercultural competence, and global understanding (Sieber \& Mantel, 2012; Townsend \& Bates, 2007). The internationalization of teacher training programs plays a significant role in teacher candidates' acquisition of these competencies.

\subsection{Current State of Teacher Training Programs and Internationalization Efforts in Turkey}

Governments have perceived the issue of teacher training as one of the top priorities. Within the scope of disseminating educational services to society, teacher training has maintained its importance in education from the very beginning of the Republic (CoHE, 2007). In that sense, there are five significant eras for improvement in teacher training after the formulation of the Council of Higher Education (CoHE) in 1982. These eras are firstly university model, which begins in 1982 with transferring teacher training from the institutes affiliated to the Ministry of National Education (MoNE) to universities governed by CoHE. Second one is the structuring efforts in 1997 with the support of "World Bank Teacher Improvement Project" (CoHE, 1998). Third one is the program renovation in 2006 parallel with European Higher Education Area and the Bologna Process (CoHE, 2007). Fourth one is the program update in 2018 connected with the curriculum development efforts for primary, middle and high school levels (CoHE, 2018), and finally the transfer of program renovation authority to the education faculties in 2020 considering some of the course alignment set (CoHE, 2020). It is imperative to state that CoHE has been the only official institution to disseminate the teacher training curricula in a top-down manner within a centralized teacher education system since 1982 .

In the current state, education faculties generally follow the teacher training program initiated in 2018 by the CoHE. According to the ongoing teacher training curricula; there is a concurrent model in which courses are divided into three specific areas simultaneously; subject area courses (\% 45-50), pedagogical knowledge courses (\% 30-35), and some general culture courses (\%15-20) (CoHE, 2018, s. 15). Field experiences are left to senior year as two separate courses for each term titled "Field Experience 1" and "Field Experience 2" and these courses must be registered to the official system of the Ministry of National Education (MoNE, 2017). Additionally, all courses developed for pedagogical knowledge and culture organize around a core curriculum in which teacher candidates from different departments jointly follow (CoHE, 2018, s.17). 
In 2020, teacher training programs in Turkey granted limited autonomy for teacher training programs (CoHE, 2020), and each faculty can develop and implement its curricula with the approval of the CoHE. With this new arrangement, the structure of courses will continue, but faculties can also initiate new curriculum norms. In this sense, it has become possible for some faculties to conduct international programs, even international partnerships in field experiences or some specific traineeship.

The participation of teacher candidates in internship activities abroad and the research related to this situation is an essential topic of discussion in the world (Barton, Hartwig \& Cain, 2015; Cushner, 2007; Goodwin, 2010; Larsen, 2016; Mahon, 2010; Nazeer-Ikeda, 2014; Shonia \& Stachowski, 2014; Smolcic \& Katunich, 2016; Spiro, 2011). According to the results of these researches, candidates who practice teaching abroad can learn how to teach in culturally diverse societies (Goodwin, 2010; Smolcic \& Katunich, 2016; Spiro, 2011), carry out a remarkable professional influence in which characteristics such as respect for the perspectives, experiences, and worldviews of different people, develop and contribute to leadership, communication skills, and self-confidence (Barton et al., 2015; Smolcic \& Katunich, 2016). It has a positive impact on the development of second foreign language teaching proficiency, especially in foreign language teachers (Smolcic \& Katunich, 2016), it changes worldviews, improves adaptability, self-confidence, empathy, and tolerance to uncertainty (Cushner, 2007; Larsen, 2016; Mahon, 2010). Nevertheless, there is not much opportunity for teacher candidates in Turkey for international traineeship programs. According to Kırkgöz (2016), the options that teacher candidates can benefit from internationally are the Fulbright Programme, Erasmus Exchanges, Work and Travel Program, and other programs in the International Relations Offices of the universities. Also, in English language teaching undergraduate programs, some programs give joint degrees at Middle East Technical University (METU) and Anadolu University. These specific teacher training curricula are created in cooperation with the State University of New York (SUNY) and require tuition fee from candidates (Anadolu University, 2021; METU, 2021). When we identify these programs, we quickly realize that there are limited internationalization structures in teacher education programs in Turkey and these structures need to be developed.

\subsection{Erasmus Exchange Program and Its General Implementation in Turkey}

Nowadays, as in other higher education programs, the individual mobility of students and academicians, the internationalization of the curriculum, and international cooperation in teacher training programs are mainly realized through the Erasmus Exchange Program (Kehm, 2005; Mutlu, 2020; Teichler, 2004; Unlu, 2015). By participating in, students at universities belonging to the "European Higher Education Area" can take part in this mobility by way of pursuing a particular piece of their undergraduate education at a university abroad or by doing an internship in an enterprise abroad (Ministry of European Affairs, 2018). From this aspect, the Erasmus program is the leading program enabling international student mobility (Kondakçı, 2003; Selvitopu, 2015). The program also forms one of the crucial dimensions of internationalization in higher education (European Commission, 2014).

The Erasmus program began in 1987 with the mobility of as few as 3,244 students coming from 11 European countries. However, according to the data obtained recently, approximately 230,000 students per year have spent an education period of between 3 and 12 months abroad "to experience a rich period of learning in other countries." Up to the present, three million students have participated in the Erasmus program in more than 4,000 higher education institutions throughout Europe, ensuring that the Erasmus program has become the most widely recognized exchange program in the world (Feyen \& Krzaklewska, 2013).

Turkey joined the Erasmus program, which is a lifelong learning program, in 2004. The aim of this program, which is maintained subject to the Center for EU Education and Youth Programs, is to encourage collaboration between universities and countries, to enable reciprocal exchanges of students and educators in Europe, to have academic recognition and improvement of transparency in studies and diplomas (Yücel, 2013). In 2018, 44930 participants in 1417 Turkish projects benefited from mobility in higher education, vocational education and training, school education, adult learning and youth for a total grant amount of $€ 83.96$ million, according to the information obtained from EU Commission. Between the years 2010 and 2018, 17957 students (for studies mobility) and trainees (for traineeship mobility) had a chance to go abroad with the program in Turkey. Furthermore, the top three sending higher education institutions in Turkey were Ankara University, Anadolu University, and Hacettepe University. However, the top three receiving countries for students were Poland, Germany, and Italy (European Commission, 2018a).

The European Commission has announced that encompassing the years 2021-2027, Erasmus grants in areas such as education, youth, and sport will be continued, and the scholarships given within the framework of the new program, and therefore the number of participants taking part in the program, will be trebled. Since the 
beginning, the Erasmus program has granted scholarships to around four million participants, and scholars expect that the new program will give scholarships to about 12 million more participants (European Parliamentary Research Service, 2018). Turkey became a member of this new scheme by signing an agreement to grant the association status for 2021-2027 (Youthnetworks, 2021). Connectedly, the program initiated brand new priorities such as inclusion and diversity, digital transformation, environment and fight against climate change, participation in democratic life, and civic engagement with publishing the new handbook for participating organizations. In terms of teacher education, the most notable difference is the latest project type (cooperation among organizations and institutions) called "Teacher Academies" under the scheme of "Erasmus+ Key Action 2." The overall objective of this action is to initiate new cooperation types of European teacher education institutions and develop an international outlook in teacher education. These academies will embrace multilingualism and cultural diversity, build teacher education in line with the EU's priorities in education policy and contribute to the objectives of the European Education Area (European Commission, 2022).

\section{Framework of the Study}

We developed an in-depth literature analysis (see Table 1) to generate the framework (see Figure 1). According to the results, five vital areas emerge within internationalizing teacher education through the Erasmus program.

Table 1. Academic Literature on Framework of the Study

\begin{tabular}{|c|c|c|}
\hline $\begin{array}{l}\text { Framework Developed by } \\
\text { Researchers }\end{array}$ & Academic Literature & \\
\hline $\begin{array}{lr}\text { Effect on } & \text { teaching } \\
\text { perspectives } & \text { and } \\
\text { multiculturalism } & \end{array}$ & $\begin{array}{l}\text { Turkish Literature } \\
\text { Altuğ, Sezgin \& Önal (2019); Demir \& Demir (2009); } \\
\text { Dinçer, (2014); Ersoy (2013); Kasapoğlu-Önder \& } \\
\text { Balci, (2010); Mutlu, Alacahan \& Erdil (2010); Özdem } \\
\text { (2013); Seyhan Yücel (2013); Tekin \& Hiç-Gencer } \\
\text { (2013); Yücelsin-Taş (2013). }\end{array}$ & $\begin{array}{l}\text { International Literature } \\
\text { Barton et al., (2015); Cushner (2007); Mahon \& } \\
\text { Cushner (2002); Mahon (2010); Sharma, } \\
\text { (2014); Shonia \& Stachowski (2014). }\end{array}$ \\
\hline $\begin{array}{l}\text { Contribution to personal } \\
\text { development }\end{array}$ & $\begin{array}{l}\text { Altay (2016); Arslan (2013); Aslan Bağcı, Erdem \& } \\
\text { Erişen (2018); Bilici (2016); Elmalı (2013); Kagnıcı } \\
\text { (2016); Mizikaci \& Arslan, (2019); Mutlu (2020), Ünal } \\
\text { (2011). }\end{array}$ & $\begin{array}{l}\text { Clarke (2005); Jacobone \& Morro (2015); King } \\
\& \text { Ruiz-Gelicez (2003); Papatsiba (2005); } \\
\text { Teichler \& Janson (2007). }\end{array}$ \\
\hline $\begin{array}{l}\text { Impressions of teacher } \\
\text { training curriculum }\end{array}$ & $\begin{array}{l}\text { Boyacı (2011); Duman (2020); Efeoglu (2021); Unlu } \\
\text { (2015). }\end{array}$ & $\begin{array}{l}\text { Buchberger, Campos, Kallos \& Stephenson } \\
\text { (2000), Kabilan (2013). }\end{array}$ \\
\hline Effect on future plans & $\begin{array}{l}\text { Aktan \& Sarı (2010); Çepni, Aydın \& Kılıç (2018), } \\
\text { Efeoglu (2021). }\end{array}$ & $\begin{array}{l}\text { Bryła (2015); Daekin (2014); European } \\
\text { Commission }(2014,2018 b) \text {; Raikou \& Karalis } \\
\text { (2010). }\end{array}$ \\
\hline $\begin{array}{l}\text { Contribution to the } \\
\text { internationalization of teacher } \\
\text { education and problems } \\
\text { experienced }\end{array}$ & $\begin{array}{l}\text { Aslan \& Bayram-Jacobs (2014); Boyacı (2011); Dinçer } \\
\text { et al. (2017), Ersoy (2013), Unlu (2015). }\end{array}$ & $\begin{array}{l}\text { Addleman, Nava, Cevallos, Brazo, \& Dixon } \\
\text { (2014); Furka \& Johnsen (2017); Kabilan } \\
\text { (2013); Leutwyler et al. (2017); Shaklee (2012); } \\
\text { Shaklee \& Baily (2012); Souto-Otero, Huisman, } \\
\text { Beerkens, de Wit and Vujic (2013). }\end{array}$ \\
\hline
\end{tabular}

The first idea is the effect on teaching perspectives and multiculturalism. We perceive that the Erasmus program progressively improves participants' intercultural competence with the experience abroad (Altuğ, Sezgin \& Önal, 2019; Dinçer, 2014; Ersoy, 2013). Tolerance toward multiculturalism is another gain for teacher candidates, especially in Turkish literature (Mutlu, Alacahan \& Erdil, 2010; Tekin \& Hiç Gencer, 2013). International literature states that cultural exchange programs and overseas student teaching catalyzes internationalizing teacher education with a calling for intercultural sensitivity (Barton, Hartwig \& Cain, 2015; Cushner, 2007; Mahon \& Cushner, 2002; Mahon, 2010).

The second one is the Erasmus program's contribution to personal development. Many pieces of research widely accepts program participants' earnings, especially in terms of language proficiency, improvement of social and communication skills (Altay, 2016; Arslan, 2013; Aslan Bağc1, Erdem \& Erişen, 2018; Bilici, 2016; Elmalı, 2013; Kagnic1, 2016). Additionally, international literature offers students who participated in the program had more European identity and were inclined to pursue an international career (King \& Ruiz-Gelicez, 2003; Teichler \& Janson 2007).

The third one is experiencing different impressions of the teacher training curriculum. Within this idea, there is widely cited literature in Turkey. One of these studies was Boyac1 (2011) and Unlu (2015). They stated that teacher candidates compare the home and host institution systems, and they formed a general idea on how interactive learning, examination styles, and teaching strategies should be. Relatedly, Buchberger et al. (2000) stated that the Erasmus program supported the mobility of teacher candidates and experienced teachers in Europe 
and helped them gain various perspectives on different teacher education systems.

The fourth one is the effect on the future of teacher candidates. Aktan \& Sarı (2010), Çepni, Aydın \& Kılıç (2018) and Efeoglu (2021) state that participants in the Erasmus program always make plans internationally and they tend to transfer the internationalization into their future work life. Similarly, Daekin (2014) finds that the employability of Erasmus students in Britain is higher than non-Erasmus students because of the international experience.

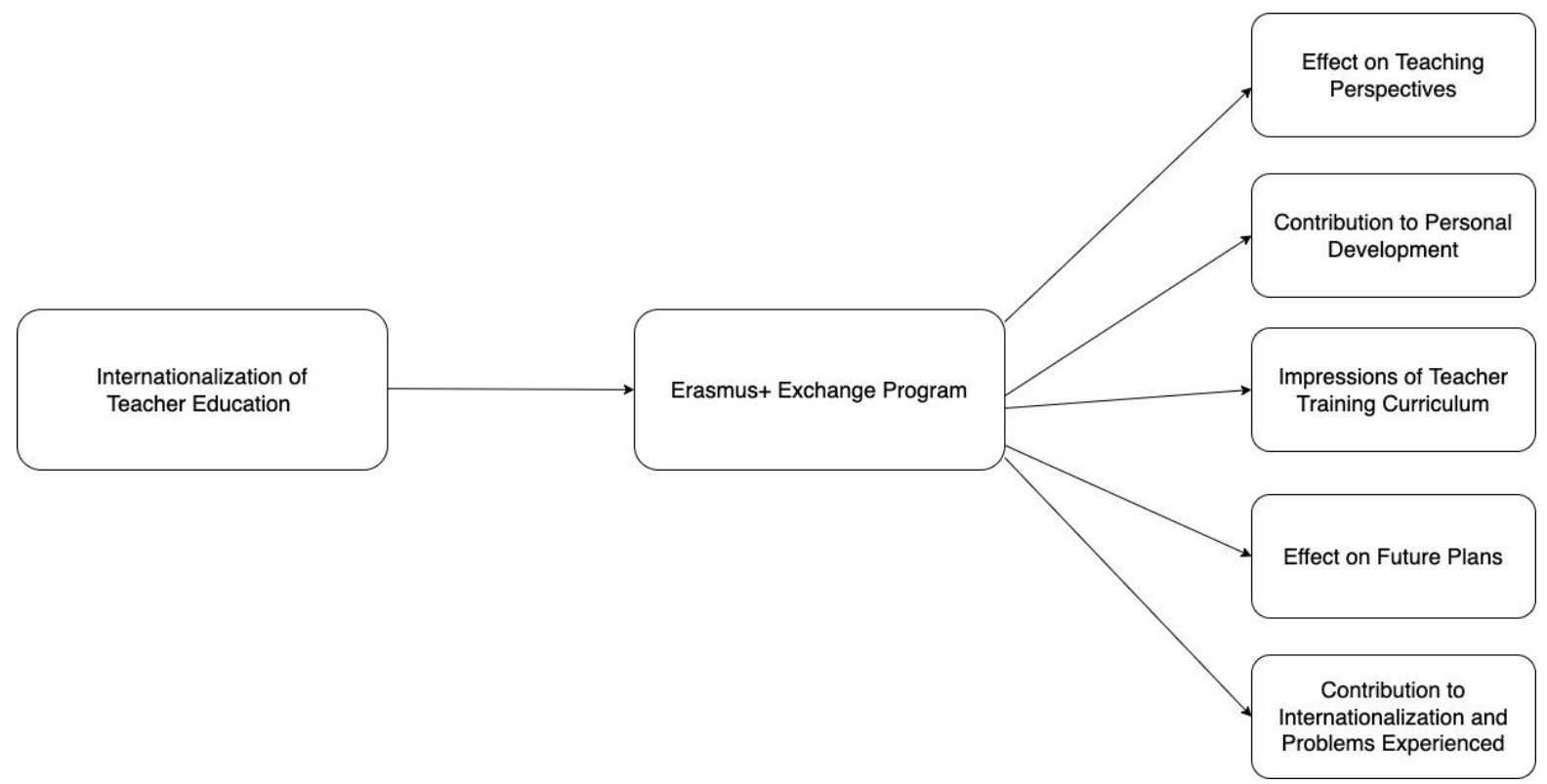

Figure 1. Framework of the Study

Lastly, but most importantly, we created the Erasmus program's contribution to the internationalization of teacher education that frames the main aim of this study. In Turkish literature, the Erasmus program is the leading international exchange in Turkey, enabling financial support for students from disadvantaged backgrounds (Aslan \& Bayram-Jacobs, 2014; Boyac1, 2011; Dinçer et al., 2017; Ersoy, 2013; Unlu, 2015). Teacher education is one area that benefits from these exchanges a lot as there are limited international opportunities for teacher candidates in Turkey (except for joint degree diploma programs for English Language Teaching Departments). In international literature, internationalizing teacher preparation is commonly expressed as a need for teacher candidates for cross-cultural experiences, knowledge of diverse cultures, and an understanding of multiculturalism, equity, and global interconnectedness (Addleman et al., 2014; Furka \& Johnsen, 2017; Kabilan, 2013; Leutwyler et al., 2017; Shaklee, 2012; Shaklee \& Baily, 2012; Souto-Otero et al., 2013). Subsequently, it is worthwhile to mention the effect of the Erasmus program in terms of the internationalization of teacher education in the Turkish context.

\section{Method}

\subsection{Research Method}

We used a case study, multiple case model, as one of qualitative research methods (Yin, 2014) and analyzed the data obtained from the cases using a cross-case synthesis. We gave the procedures conducted for this case study in Table 2. 
Table 2. Procedures for Conducting the Case Study for the Research

Steps for conducting a case study (Creswell, Measures taken in this research 2007)

1) Determine whether the case study approach is appropriate for the research problem.

2) Identify case or cases. Cases may involve an individual, several individuals, a program, an event, a situation, or an activity. The case can be single or collective, multi-site or within-site, focused on a point or an issue.

3) The data collection in case study research is typically extensive, drawing on multiple sources of information.

4) The type of data analysis can be a holistic analysis of the entire case or an embedded critique of the case. When multiple cases are chosen, with-in-case analysis and cross-case analysis are given.

5) In the final interpretative phase, the researcher reports the meaning of the case/cases.

1) We have identifiable cases with boundaries (incoming students, outgoing students, and coordinators). Likewise, internationalizing teacher education is an in-depth analysis phenomenon, with the Erasmus program being a different situation integrated into the cases.

2) We have three different cases in this study: European and Non-European teacher candidates who visited Turkish universities named "incoming students." Turkish teacher candidates who visited European teacher training institutions are defined as "outgoing students." Erasmus program coordinators in education faculties are stated as "coordinators." We seek to provide an understanding of their viewpoints of different situations.

3) Although a case study requires more than one data collection technique, the nature of the research problem enables us to use the cases with interview technique. It is impossible to observe the participants for an international experience or use audiovisual material physically in different countries. It is essential to state that we reached data saturation through interviews.

4) We analyzed the interview data by employing cross-case synthesis.

\subsection{Sampling}

In this study, we used criterion sampling, one of the purposive sampling methods. The main point in purposive sampling methods is to judge who will be able to provide the best information to achieve the aims of the study. For this purpose, it is necessary to contact people who possess this information (Creswell, 2007). Besides, Kruger (1988) and Morse (1994) proposed at least one individual in a case study (as cited in Njie \& Asimiran, 2014). The research criteria are benefiting from the Erasmus program for the incoming and outgoing students and the coordinators, as currently working as a coordinator in the education faculty of a university involved in the activities of the Erasmus program and having organized student exchanges. We present information about students and coordinators who participated in the study in Table 3. 
Table 3. Participant Information

\begin{tabular}{|c|c|c|c|c|c|c|}
\hline OS* & Gender & Grade & Department & $\begin{array}{l}\text { Country } \\
\text { Visited }\end{array}$ & University Visited & $\begin{array}{l}\text { Department } \\
\text { Attended }\end{array}$ \\
\hline S1 & Male & $\begin{array}{l}\text { 4th-year / } \\
\text { Undergraduate }\end{array}$ & $\begin{array}{l}\text { Psychological } \\
\text { Counselling and } \\
\text { Guidance }\end{array}$ & Poland & $\begin{array}{l}\text { Cardinal Stefan Wyszynski } \\
\text { University in Warsaw }\end{array}$ & Psychology, Pedagogy \\
\hline S2 & Female & $\begin{array}{l}\text { 4th-year / } \\
\text { Undergraduate }\end{array}$ & $\begin{array}{l}\text { Psychological } \\
\text { Counselling and } \\
\text { Guidance }\end{array}$ & Croatia & $\begin{array}{l}\text { Josip Juraj Strossmayer } \\
\text { University of Osijek }\end{array}$ & Psychology, Pedagogy \\
\hline S3 & Female & $\begin{array}{l}\text { 3rd-year / } \\
\text { Undergraduate }\end{array}$ & $\begin{array}{l}\text { Primary Classroom } \\
\text { Teaching }\end{array}$ & Slovenia & University of Primorska & $\begin{array}{l}\text { Primary Classroom } \\
\text { Teaching }\end{array}$ \\
\hline S4 & Female & $\begin{array}{l}\text { 3rd-year / } \\
\text { Undergraduate }\end{array}$ & $\begin{array}{l}\text { Psychological } \\
\text { Counselling } \\
\text { and Guidance }\end{array}$ & Croatia & $\begin{array}{l}\text { Josip Juraj Strossmayer } \\
\text { University of Osijek }\end{array}$ & $\begin{array}{l}\text { Psychology, } \\
\text { Philosophy }\end{array}$ \\
\hline S5 & Female & $\begin{array}{l}\text { 4th-year / } \\
\text { Undergraduate }\end{array}$ & $\begin{array}{l}\text { Mathematics } \\
\text { Teaching }\end{array}$ & Belgium & University College Ghent & Social Service \\
\hline IS* & Gender & Grade Level & Home Department & $\begin{array}{l}\text { Home } \\
\text { Country }\end{array}$ & Home University & Host Department \\
\hline S6 & Female & $\begin{array}{l}\text { 3rd-year / } \\
\text { Undergraduate }\end{array}$ & $\begin{array}{l}\text { Social Science } \\
\text { Teaching }\end{array}$ & Spain & Universidad de Salamanca & $\begin{array}{l}\text { Educational Sociology } \\
\text { (Master) }\end{array}$ \\
\hline S7 & Female & $\begin{array}{l}\text { 3rd-year / } \\
\text { Undergraduate }\end{array}$ & $\begin{array}{l}\text { Social Science } \\
\text { Teaching }\end{array}$ & Spain & Universidad de Salamanca & $\begin{array}{l}\text { Educational Sociology } \\
\text { (Master) }\end{array}$ \\
\hline S8 & Female & $\begin{array}{l}\text { 2nd-year / } \\
\text { Postgraduate }\end{array}$ & $\begin{array}{l}\text { Educational } \\
\text { Sciences }\end{array}$ & Germany & University of Tubingen & $\begin{array}{l}\text { Educational Sociology } \\
\text { (Master) }\end{array}$ \\
\hline S9 & Female & $\begin{array}{l}\text { 4th-year / } \\
\text { Undergraduate }\end{array}$ & $\begin{array}{l}\text { Turkish Language } \\
\text { and Literature }\end{array}$ & $\begin{array}{l}\text { Bosnia- } \\
\text { Herzegovina }\end{array}$ & University of Tuzla & $\begin{array}{l}\text { Turkish Language } \\
\text { Teaching }\end{array}$ \\
\hline $\mathbf{C}^{*}$ & Gender & Seniority & $\begin{array}{l}\text { Location of } \\
\text { University }\end{array}$ & Experience & $\begin{array}{l}\text { Estimated Number } \\
\text { of Outgoing Students** }\end{array}$ & $\begin{array}{l}\text { Number of } \\
\text { Incoming Students }\end{array}$ \\
\hline $\mathrm{C} 1$ & Female & 25 years & Central & 4 years & 200-250 students & $20-30$ students \\
\hline $\mathrm{C} 2$ & Female & 18 years & Central & 15 years & 100 students & $20-30$ students \\
\hline $\mathrm{C} 3$ & Male & 11 years & Provincial & 5 years & 40 students & $5-10$ students \\
\hline
\end{tabular}

*OS=Outgoing Student, IS= Incoming Student, C=Coordinators

**The numbers are for the whole institution, not especially education faculties.

\subsection{Data Collection}

The research data were collected using semi-structured interview forms. The first author of the research created this interview form by reviewing the literature. Then, researchers gathered expert opinions for the interview questions. We restructured the first question as two separate questions based on the views obtained. To be more clearly understood, we added a further question to the interview form to the connection between the Erasmus program and internationalization. Examples of the interview questions were given below here:

-Considering that you have participated in Erasmus Program, do you think you have a different perspective on being a "teacher"? If so, how? (Students)

-How did the Erasmus Exchange Program contribute to your personal development? Can you evaluate yourself for social skills, academic qualifications, teaching skills? (Students)

-What is your positive and negative experience about the teacher training system in the host university when you compare it to your design in home university? (Students)

-Can you talk about the social skills, academic competencies, and professional teaching skills that the Erasmus+ program has given to your outgoing students? Is there a contribution or not? What is your opinion? (Coordinators)

-How do you think the Erasmus program contributes to the international dimension of teacher education in Turkey? Can you evaluate it in terms of internationalization? (Coordinators)

We collected data from students and coordinators who participated voluntarily in the study via online visual and audio programs. The interviews held with the students lasted about forty minutes, while the discussions made 
with the coordinators took approximately one hour. Afyon Kocatepe University's Research and Ethics Committee granted ethical approval for this study.

\subsection{Data Analysis}

We analyzed the research data from the semi-structured interviews with codes and coding techniques (Miles \& Huberman, 1994). This technique requires the data to be organized and managed in some form by assigning 'tags' or 'labels' to the data collected. This process is referred to as coding (Coffey and Atkinson, 1996). For example, a code might identify a word, a phrase, a sentence, or a paragraph important to the research. The code attempts to associate meaning to these chunks of data. (Miles and Huberman, 1994:56) and this requires an appreciation of the data you are working with (Dey, 1993). Therefore, the person undertaking the data collection process is ideally suited to be the person who will also perform the function of coding this data (as cited in Atkinson, 2002). Within codes and coding technique, we followed these steps below (Atkinson, 2002, pp. 2-4):

- Step 1: Create the data repository. To analyze the data from the case studies, it has to be in a format that allows easy manipulation. To do that, we transcribed the interviews and expanded a schema by reading the discussions from the beginning.

- Step 2: Define codes: Initial codes, expanded codes, rationalized codes. Once the transcriptions were ready, we organized and managed "tags" or "labels" to the data collected. We created the initial principles, then developed them into expanded codes and evolved expanded codes into rationalized codes (by deleting, merging, and leaving the codes over and over again).

- Step 3: Analysing the coded data. After the data entry is completed and the codes have been rationalized, the data analysis begins. In this stage, we concluded the content analysis to coded data.

- Step 4: Final propositions. We grouped the rationalized codes into themes.

To increase the study's credibility, Guba and Lincoln (1982) expressed trustworthiness to persuade the audience that the findings of an inquiry are worth consideration in terms of arguments, criteria, and research questions. To enable trustworthiness in the study, we used the specific criteria suggested by Creswell (2007) and Guba and Lincoln (1982). According to these criteria, we ensured trustworthiness with long-term interaction, co-researcher examination, rich and in-depth description, and explanation of the position of the researchers in the study.

Within the scope of long-term interaction, we obtained an adequate depth of data by allocating sufficient time to the participants. Regarding co-researcher examination, the second researcher checked the research, and we mutually monitored the study with regular "co-researcher investigation sessions." About detailed and in-depth descriptions, we made broad and careful descriptions of the location, context, and culture, and we gave the data collected from the participants together with opposing views.

Finally, we consider it is necessary to share the position of the researchers within this scope. The authors of the study consist of one university member tasked with conducting the Erasmus program and one coordinator tasked with leading the Erasmus program in an education faculty at two different public universities located in Turkey. Therefore, we say that the researchers fully acknowledge the context in which the research was conducted.

\section{Results}

\subsection{Effect on Teaching Perspectives and Multiculturalism}

As shown in Table 4, the similarities between incoming and outgoing students are perspectives on experiencing different cultures, tolerance toward multiculturalism, and fostering open-mindedness and empathy. The differences are for outgoing students' improving practical teaching methods with sharing other teacher education systems and for incoming students' bridging with different nations and possessing the feeling of more European.

The students who participated in this research commonly expressed that experience abroad influenced their professional teaching perspectives regarding respect for multiculturality. All of the outgoing students underlined this contribution to the program. A student stated it as;

“....So I am thinking of becoming a teacher anyway. At least in a certain part of my profession, I plan to teach, albeit in private institutions. It has benefited me in that respect. When you see different cultures, personalities, and different types of people, people get used to it a little more and think that teaching can become a little easier. As a result, people develop the idea that I can teach a little more, I can succeed a little more." (S1-Outgoing-Poland).

Multiculturality is an essential effect of Erasmus's experience for teacher candidates. They gain cultural awareness and discover the varieties of cultures. Previous intensive research findings also support this idea (Altuğ, Sezgin \& Önal, 2019; Demir \& Demir, 2009; Dinçer, 2014; Ersoy, 2013; Kasapoğlu-Önder \& Balci, 
2010; Mizikaci \& Arslan, 2019; Mutlu, Alacahan \& Erdil, 2010; Özdem, 2013; Seyhan Yücel, 2013; Tekin \& Hiç-Gencer, 2013; Yücelsin-Taş, 2013). According to these results, the Erasmus program has a facilitative influence on the intercultural communicative perception of the participants, and they have a chance to get to know their own culture in a foreign country.

Table 4. Qualitative Finding 1 (Effect on Teaching Perspectives)

\begin{tabular}{lll}
\hline & Theme & Codes \\
\cline { 2 - 3 } & & Gaining perspective on multiculturalism \\
Effect on Teaching Perspectives & Eutgoing Students & Experiencing different teacher training systems \\
& & Fostering empathy, open-mindedness, and tolerance \\
& Gaining practical teaching methods \\
& Connecting with different nations \\
& Get to know different cultures \\
& Incoming Students & Enabling the feeling of Europeanization \\
& Being more open-minded \\
\hline
\end{tabular}

Another finding is that they observe the differences in teaching with the help of field experiences in actual classrooms. A student explained that the field experience had fostered a more positive attitude toward the teaching profession. She learned different teaching methods and techniques because of the limited field experiences in Turkish teacher education programs compared to the host institution in the foreign country:

"I think it changed my teaching perspectives. In the end it is impossible to resist that change. I studied there in another education system, and there are some interesting aspects to me. In the future when I have a problem in the classroom, when children do not understand something, I think that I can use the methods learned there. I gained a more practical knowledge in this way. I made observations and went to schools like internships. I have also been in a primary school; I have observed that those children learn better with practical learning methods. This practical teaching is not used much in our country. In this way, for example, I can teach better in my classroom in the future. I can do more with such games and dramas. I am mathematics teacher, I can teach mathematics in this way. Indeed, that's how they taught mathematics in Belgium. I was quite surprised. Frankly, I am sure that studying in Erasmus gave me a vision as a teacher, and I think everyone should go. I don't even understand why no one from the Faculty of Education applies such international exchange opportunities" (S5-Outgoing-Belgium).

Mizikaci and Arslan (2019) support this finding, with expressing that program participants develop new perspectives to solve problems and learn different techniques/practices of their study fields. As seen from the quotation above, teaching courses abroad significantly impact teacher candidates (Barton et al., 2015; Cushner, 2007; Mahon, 2010; Sharma, 2014; Shonia \& Stachowski, 2014). But unfortunately, most of the students couldn't have a chance for field experiences or practicing opportunities during their experience abroad (Kissock \& Richardson, 2010). Accordingly, teacher candidates in the Erasmus program generally take physical or online courses instead of observing or teaching in a classroom. This situation can stem from the reality that field experience I and II are compulsory courses in teacher training curricula in Turkey, and it is impossible to equalize it with another course abroad. The best offer would be to take extra international internship opportunities for teacher candidates in that case.

Besides the respect felt toward multiculturality, both outgoing and incoming students stated that the Erasmus program developed their world views concerning schooling and enabled them to experience different teacher training systems. As teachers, it fostered empathy, open-mindedness, and tolerance toward students. S2 best explained this situation:

"Some people are such that never mind leaving the city forget about leaving one's own country; they don't even leave their neighboring area. Therefore, I broadened my worldview considerably. It is also just as important for a student in the education faculty since we can practice teaching very different techniques. I discover that there are varieties of teaching styles outside the education system we have seen for years in Turkey." (S2-Outgoing-Croatia).

In the European Commission (2014) study, candidates reported improved soft skills, such as knowledge of other countries, their ability to interact and work with individuals from different cultures, adaptability, and communication skills. Additionally, $99 \%$ of the higher education institutions saw a substantial improvement in 
their students'confidence and adaptability.

Unlike the outgoing students, however, the incoming students stated that participation in the Erasmus program as teacher candidates would enable "Europeanization" in the teaching profession by overcoming prejudices. Students coming from Europe would connect with students from other nations more easily.

"Yeah. It did change something in me that is not like being a teacher but a full view of the world. After my first Erasmus, I felt more European, more connected to like the different nationalities and Europe as a whole idea, which changed my perspective-not especially being a teacher. But may influence how you would teach like more open-minded view. Maybe more how people think about different countries and how many prejudices are told about different countries not true." (S8-Incoming-Germany)

Contrary to the finding above, Sigalas $(2009,2010)$ reports that while Erasmus enables students to learn more about other European countries, it does not promote European identity. The reason is that contact with the students in the host country can remain limited. So, it would be a good idea to increase the interaction among teacher candidates. In this research, the participant expressed this comment not because of the identity building but because of the feeling free from prejudices in a European style. When we compare the views, we can see that the contribution of the Erasmus program to internationalization in teacher training programs was realized through specific social competencies like empathy and tolerance towards different nationalities, cultures, and individuals.

\subsection{Contribution to Personal Development}

As in the contribution to teaching, social skills were at the forefront of the students' personal development, while academic competencies and professional teaching skills were kept in the background. Mutlu (2020) supports this finding, who expresses that the Erasmus experience is a highly beneficial period for students; it develops personally rather than academically. This situation was more clear in the views of outgoing students and coordinators. The incoming students found the academic education they received in Turkey to be more adequate than expected. Also, the students and coordinators mainly reported that their social skills, such as the ability to get on well with different people in different cultures developed, besides by living in another country on their own, they improved their self-confidence and foreign language skills:

“...My roommate was Croatian, and I learned to get on with someone outside my own culture. Not only did I learn to respect her language and religion, but she was also very respectful toward me. It was an enjoyable experience for me, and all my Erasmus friends came from different countries with different ideas. Some people broadened my horizons." (S4-Outgoing-Croatia).

"Above all, my self-confidence developed at once because when I went for Erasmus, I boarded a plane for the first time and went abroad for the first time in my life, and while going abroad, I was completely on my own. Nobody went there with me or did anything in any way" (S1-Outgoing-Poland).

Table 5. Qualitative Finding 2 (Contribution to Personal Development)

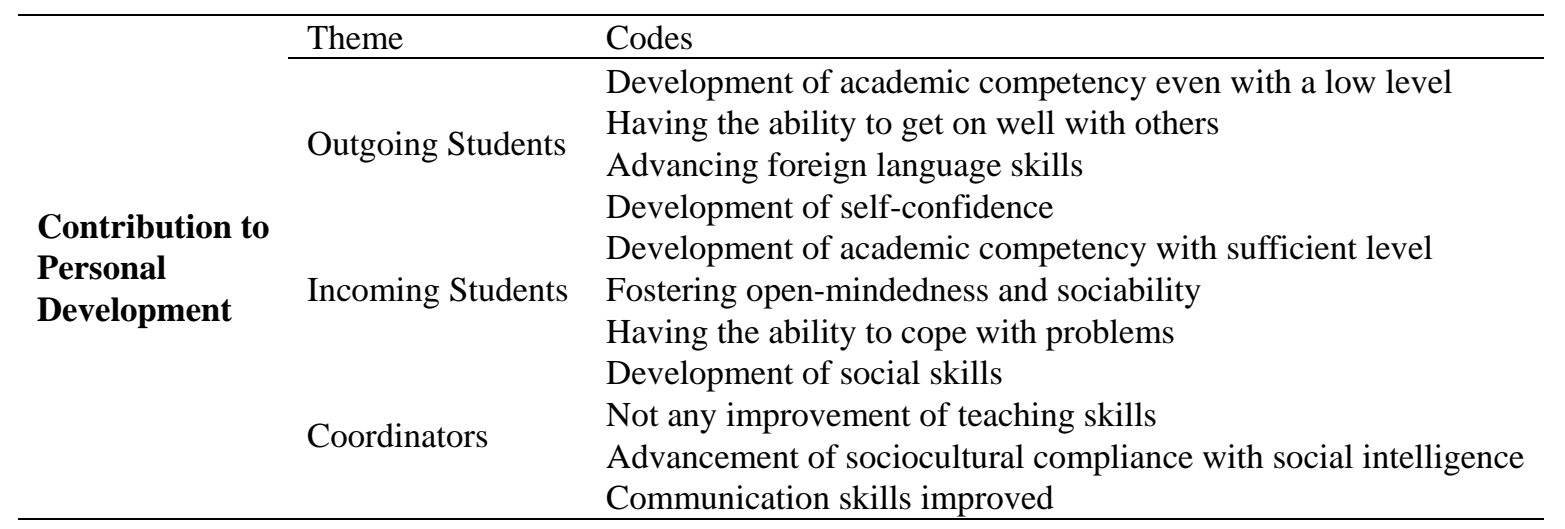

As well as developing their self-confidence, this situation also shows that the Erasmus program was an excellent opportunity financially for teacher candidates from families with low or medium socioeconomic levels. However, a unique position in the development of social skills was not reflected in the same way in academic development. This finding was seen most clearly in the views of coordinators. A coordinator (C1) employed in a central university stated that while students' social skills developed, their academic competence did not, and the coordinator (C2) in another major university said that academic improvement also changes depending on the 
education level the university visited. In other words, the academic level of the host university affects educational improvements in Erasmus students positively or negatively. This finding reveals that teacher educators should make field-based exchange agreements with more effective and prosperous universities in Europe:

"Social skills are given more prominence. But I do not believe that it leads to a great deal of change about the teaching profession or completion of the process of the teaching profession." (C1-Female-Central);

"The most developed aspects are social skills. Academic competence rather depends on the university that is visited." (C2-Female-Central)

In parallel with the students' views, coordinator (C3) stated that teacher candidates on the Erasmus program could develop their own psychological and sociocultural compliance and social intelligence in students. Additionally, they grew in terms of teaching by improving their communication skills:

"When students go to another country, enabling the sociocultural compliance, in fact, the ability to adapt, to conform to a new environment, also corresponds in a way to the definition of intelligence. Language is the first dimension of this adaptation process that we call sociocultural compliance. Regarding the language dimension, I have seen that our outgoing students have greatly developed themselves and made many friends from overseas, especially in recent years. Communication skills are essential for us in education faculties. This communicative competence is also positive in terms of teaching." (C3-Male-Provincial)

Also, their language skills and self-confidence increased, they enabled psychological resilience in their well-being:

"The fundamental concept is resilience. Students have improved a lot at this point. For example, before the Erasmus process, I had a student who thought about giving up a lot. She was fed up with the paperwork. I was always trying to explain this process. When students first come and say that they will go to Erasmus, they say that I will go abroad, it will be very nice. They think like going to travel or something. But they don't realize that it is a tough fight. I have experienced the same. Living abroad is difficult, but students are not very aware of it. This hardness starts during the visa process. The student begins to feel tired and it is not easy. But in this process, students are looking for support. As coordinators, we provide support in this regard. Of course, there will be difficult things, not everything will be easy, but we convince the student that the result will be good for them. For example, they must keep up with the use of the common kitchen; they see the cleaning practices of different countries. Sometimes the student gets very angry; they can't adapt. Sometimes they complain to us. But at the end of this process, they come back stronger than I see them. Because I think the resilience happens in students." (C3-Male-Provincial)

This view shows that the Erasmus program's contribution to personal development was primarily realized in social, communicative skills, and psychological resilience. The coordinators also reported that they observed this improvement, but the program should be developed to have a more significant effect in an academic sense. Cardwell (2020) stated that law school candidates who participated in the Erasmus program increased their chances of gaining higher overall grades in their degrees. However, the evidence showed that this impact was less than expected on overall average grades, with an average of 2\%-3\% differentiating those who chose a year abroad from those who did not. So, we say that academic improvement in the program is specific to the area or the academic success of the host university. Generally, students do not primarily undertake study abroad because it will help them achieve higher grades. Still, most see the opportunity to gain maturity and career-enhancing prospects as key.

\subsection{Impressions of Teacher Training Curriculum}

Within the curricular scope, both incoming and outgoing students had the opportunity to experience the teacher training curriculum of the host country. They made further comments in this context. The outgoing students stated that compared to Turkey, they saw that there were less theoretical knowledge and more teaching practice in teacher training:

"....Generally, hardly any course is theoretical. They are all practical. They continually prepare a game. Well, we only go to schools in the final year. The course in their university teaching department is three years. It's as if they do a three-year internship." (S5-Outgoing-Belgium).

Another view was that pedagogical courses and professional teaching knowledge were similar:

"It's generally similar to ours. Thus, there are both subject-based and conceptual courses within the framework of general education." (S1-Outgoing-Poland). 
Table 6. Qualitative Finding 3 (Impressions of Teacher Training Curriculum)

\begin{tabular}{lll}
\hline & Theme & Codes \\
\cline { 2 - 3 } $\begin{array}{l}\text { Impressions of } \\
\text { Teacher }\end{array}$ & Outgoing Students & Less theoretical knowledge and more teaching practice \\
Training Curriculum & & Similar courses for pedagogical knowledge and field study \\
& Impression of students better academic competencies \\
& Incoming Students & Different certification paths of teacher candidates \\
& $\begin{array}{l}\text { Better physical facilities } \\
\text { Fewer class sizes }\end{array}$ \\
\hline
\end{tabular}

We see that the program contribute to the professional competencies of candidates. It is effective in observing both similar and different teacher training models. As such, Unlu (2015) stated that the academic gains of the teacher candidates in the program are interactive learning, professionalism, different teaching strategies. Connectedly; the impressions of incoming students about the teacher training programs were that in Turkey, class sizes in this program were smaller, and students received a more effective education by being separated into classes:

"In Spain, there are 100 people in our classes, which are not very effective concerning instruction. But in Turkey, we have one-to-one lessons with the professors. It was very beneficial for us in an academic sense." (S7-Incoming-Spain).

In line with this idea, Boyac1 (2011) stated that according to incoming students in education faculties, the examination system and physical conditions were more advantageous than home university, and the class sizes were less than expected. Overall, by studying in different countries, students experience teacher training curriculum in the host country and compare their curriculum with those they visited. Observing good practices in situ helped them acquire ideas about instruction.

\subsection{Effect on Future Plans}

Students' participation in the Erasmus program impacted their lives and allowed them to shape their plans from an international perspective. Both outgoing and incoming students stated that they wished to experience the Erasmus program again. It brings to mind the slogan, "Once Erasmus, always Erasmus," that expressed among students:

"It was effective because once that overseas door opened to you, once you have been abroad, people always make plans, or at least I do, to go abroad. The overseas option is now always open for me. In the simplest terms, I am thinking of studying for a master's and applying for the Erasmus program again while doing my master's." (S1-Outgoing-Poland)

This finding shows how much students had developed socially and culturally after taking part in the Erasmus program. Most of the incoming students stated that they had achieved the competence to be able to study and work in Turkey or another country abroad:

"After my Erasmus study, I also want to do a master's in Turkey. Since I study Turkish language teaching, I think that will be beneficial in terms of my academic career." (S9-Incoming-Bosnia).

Table 7. Qualitative Finding 4 (Effect on Future Plans)

\begin{tabular}{lll}
\hline & Theme & Codes \\
\cline { 2 - 3 } Effect on Future Plans & Outgoing Student & Making plans for going abroad \\
& & $\begin{array}{l}\text { Contribution to an academic career } \\
\text { Participating in Erasmus program once more } \\
\end{array}$ \\
& Study or work in Turkey again \\
Incoming Students & $\begin{array}{l}\text { Having the chance to work in other European countries } \\
\text { Participating in Erasmus program once more }\end{array}$ \\
\hline
\end{tabular}

In this regard, the Erasmus program had a positive impact on outgoing students and students coming to Turkey from overseas. Incoming students began making career plans in a different country by learning about teacher training programs in Turkey. Similarly, European Commission $(2014,2018 b)$ highlights identical results. According to these researches, even five to ten years after graduation, the unemployment rate of mobile students is lower than non-mobile students. They have a more international life and are more likely to live abroad. In conclusion, when students went to study in another country independently of their own families, albeit, for a 
short period, this developed their social and cultural skills and allowed their plans to change in an international direction.

\subsection{Contribution to the Internationalization of Teacher Education and Problems Experienced}

We investigated the Erasmus program's contribution to the internationalization of teacher education curricula and the problems experienced in this process through interviews with the coordinators. Since coordinators are responsible for conducting this program in their faculties, they are more experienced and accumulate knowledge about the problems encountered. We see that the coordinators have different views about the contribution of the Erasmus program to internationalization in teacher education programs. One coordinator (C1) stated that the program was not effective in this regard, and for this effect to be realized, first, the quality of national standards had to be improved:

"In my opinion, it is, in fact, first necessary to improve the quality of national standards before this international process, though not about the Erasmus program. In fact, after general standards within teacher training programs have first been provided, where we are in the national framework in terms of teacher education? When we make this comparison in the national framework, we must look at which of our points are at the forefront and which points are in the background." (C1-Female-Central).

Another coordinator $(\mathrm{C} 2)$ stated the effect of the Erasmus program on the internationalization of teacher education to be that because of the Bologna Process, the courses with the ECTS system and workloads determined:

"Now, of course, our field has a national intensity. The field of teacher education is a field that grows and develops with national identity codes in terms of culture and knowledge. However, serious distances have been covered in Europe and at home to contribute to internationalization. Processes such as the accreditation of courses, the determination of workloads, the equalization or equivalence of course hours, and a move toward higher education that facilitates change have had an impact on many systems in Europe." (C2-Female-Central)

Coordinator $\mathrm{C} 3$ stated that the Erasmus program made an outstanding contribution to teacher candidates' lifelong learning. The ones who went on Erasmus once sustained participation in different Erasmus projects by encouraging their students throughout their teaching lives and said that the program contributed to internationalization in this field:

"For example, I had a student who went on Erasmus from mathematics education. We sent her with difficulty, saying, "Come on, you can do it!" She thought that she would never go abroad, and if she had given up at that moment, she would never have gone abroad in his life. But now I see that she goes abroad on vacation and writes Erasmus school education projects in her school. Students who go on Erasmus do not want to break their bond with Erasmus. I think that the Erasmus program means lifelong learning, or it is useful for that concept." (C3-Male-Provincial).

Furthermore, coordinator $\mathrm{C} 3$ outlined that the Erasmus program makes outstanding contributions to teacher education that is becoming universal by its very nature recently.

"Teacher education is not national; in contrast, we are trying to bring something universal here. Our young population is substantial now. Some of them will look for opportunities for a career abroad, not in Turkey. Even in pre-school, some kindergartens are looking for bilingual teachers. In this sense, I do not think that a student who goes to Erasmus is under the same conditions as a teacher candidate who has received his education completely in Turkey. But I haven't been able to explain this to the students in my faculty for years. Because their language proficiency is below the average, they cannot go to Erasmus. They can't even think about the opportunities of attaining language proficiency. They can't imagine." (C3-Male-Provincial). 
Table 8. Qualitative Finding 5 (Internationalization of Teacher Education)

\begin{tabular}{lll}
\hline & Main Theme & Codes \\
\cline { 2 - 3 } & $\begin{array}{l}\text { Contribution to the } \\
\text { internationalization of } \\
\text { teacher education }\end{array}$ & $\begin{array}{l}\text { Impact on lifelong international learning } \\
\text { Internationalization } \\
\text { of Teacher } \\
\text { Education }\end{array}$ \\
\cline { 2 - 3 } & $\begin{array}{l}\text { Improving the quality of national standards } \\
\text { before the international process } \\
\text { Ensuring course load and ECTS credit system }\end{array}$ \\
\hline Problems experienced & $\begin{array}{l}\text { No improvement in teaching skills of teacher candidates } \\
\text { Lack of field study due to course non-availability } \\
\text { Lengthy procedures of the Erasmus program } \\
\text { Problems of English language level in the } \\
\text { country of destination }\end{array}$ \\
\hline
\end{tabular}

These findings reveal that the Erasmus program contributes to the internationalization of teacher education. Although there were opinions among the teacher educators that the Erasmus program did not enable academic development $(\mathrm{C} 1)$, the program must trigger the Bologna Process and activate credit transfers. It develops students in terms of social and communicative skills, which can be given as examples of the contribution.

The coordinators' views on problems related to internationalization in teacher education differed. While one coordinator (C1) stated that due to the incompatibility of courses in countries visited for Erasmus, the practicum course was inadequate. She was opposed to the practicum during the Erasmus program. Another coordinator (C3) believed that rather than having curricula full of theoretical knowledge, the development of teacher candidates' social skills would improve their teaching skills in the future better. However, this coordinator made this comment on teacher training programs at the primary school level:

"There is at the moment no secondary level teaching program in our faculty. Therefore, do students ever see differential equations at primary school in the first eight years? Or, for example, students do not need that analysis in primary school. The extent to which such detailed programs contribute to student teachers' future teaching skills should be debated. Several social skills are more important for being a teacher. That is, being able to get on with people, for example." (C3-Male-Provincial).

While on the one hand, this situation stresses the need to develop students' communication skills. On the other, it reveals a conflict between theory and practice in teacher education programs. Eret-Orhan, Ok, and Çapa-Aydın (2018) found that field experiences are the least adequate component in Turkey among all aspects of teacher education, while the practicum component is crucial to help candidates practice. Other problems seen by coordinators in the context of internationalization are the struggle with lengthy procedures by students who participate in the Erasmus program and problems related to teaching courses in English in the country and university visited:

"So they have great difficulty before they go. The procedures are long, and they must do many things. Finding a compatible course, obtaining the coordinator's signatures in full, and completing the legal procedures, you see many things to do. It's passports, visas. Of course, after doing all these and going, they come back with wonderful self-confidence and happiness." (C2-Female-Central);

"Well, did our students have big problems or didn't they? But in Italy, they did; they canceled the course. There is not a course in English. They told the student to take a course in Italian. So, the student failed." (C3-Male-Provincial).

Given above quotations, we saw problems such as academic competencies, course selection, lengthy legal procedures, and issues associated with communicating in a foreign language. Even so, the teacher candidates improved themselves in an international context with the Erasmus program. Studies (Aslan \& Bayram-Jacobs, 2014; Dinçer et al., 2017; Mizikaci \& Arslan, 2019) also highlighted the problems of filling out the application documents as challenging tasks and course compatibility problems during the procedure. Besides, Souto-Otero et al. (2013) stated the barriers to international mobility as insufficient financial help study abroad, recognition problems, and social personal reasons.

\section{Discussion}

Teacher education is generally an open and dynamic system and is also a process that continually progresses (Buchberger et al., 2000). Therefore, as the world becomes more globalized, teacher educators must keep up with this globalization to prepare teacher candidates for the future (Kissock \& Richardson, 2010). One of the most crucial dimensions in this globalization felt is internationalization in teacher education. Nowadays, 
internationalization in higher education programs is most frequently realized through the Erasmus program. Created by the European Commission in 1987, the Erasmus program enables an intensive exchange of personnel in Europe and supports 100,000 students annually. In this respect, some experts consider the Erasmus program is to be the most successful policy reform among European Union policies (Altbach \& Teichler, 2001). For this reason, in this study, the views on internationalization in teacher training programs in Turkey are analyzed through participants or coordinators of the Erasmus program.

Firstly, in parallel with other research findings, teacher candidates who gained international learning experience reported that they developed a more positive attitude toward the teaching profession (Mahon \& Cushner, 2002; Stachowski \& Sparks, 2007; Vorkapic, 2016), made gains in their personal development, principally in personal and professional identity (Aslan \& Bayram-Jacobs, 2014), gained different impressions of teacher training (Aydarova \& Marquardt, 2016; Mahon, 2010), and included overseas studies in their plans (Goldstein, Trahar, \& Yemini, 2019).

Secondly, the coordinators stated that teacher candidates' social skills such as empathy, intercultural awareness, and tolerance developed (Dooly \& Villanueva, 2006; Larsen, 2016; Shaklee, 2012; Shaklee \& Baily, 2012; White, 2016), but there were deficiencies in academic competencies, and for this reason, teacher candidates less prefer international exchange programs (Kissock \& Richardson, 2010). The other problems experienced were inconsistent course loads and credits in the programs created problems in academic recognition processes (Vorkapic, 2016), and inadequate foreign language skills could pose an obstacle to internationalization (Kehm, 2005; Mazeikiene \& Loher, 2008).

Thirdly, outlining the Erasmus program's contribution to internationalization in teacher training programs, the outgoing students reported that being multicultural in their teaching perspective broadened their world views. According to Shaklee \& Baily (2012); it is vital to try identifying the elements of "cross-cultural experiences, knowledge of diverse cultures, an understanding of globalization, perceptual, interpersonal and communication skills that enhance the ability to work with and learn from people different from themselves and certain shared beliefs and values that support diversity, equity and global interconnectedness" and be more proactive about engaging teacher education programs to develop these qualities. Consequently, the Erasmus program is a tangible way of promoting given features here.

Considering the skills fostered, teacher candidates made progress toward the pedagogical approaches such as flexibility, adaptability, autonomy, and creativity, highlighted by some studies as necessary qualities to cope with multicultural societies (Sieber \& Mantel, 2012; Townsend \& Bates, 2007). Similarly, the incoming students said that the same social skills developed, but they enabled their ability to cope with problems and identity changes like Europeanisation. Still, we see that many studies found significant changes occurred in outgoing and incoming students' social skills, foreign language development, and especially developing tolerance towards multiculturalism (Dooly \& Villanueva, 2006; European Commission, 2014, 2018; Kehm, 2005; King \& Ruiz-Gelices, 2003; Larsen, 2016; Maiworm \& Teichler, 2002; Sigalas, 2009; Turkish National Agency, 2009). This study also confirms these findings.

Fourthly, about the Erasmus program's effect on their plans, both groups stated that because of the Erasmus program, they were more willing to study again, do an internship, or work in a foreign country. Moreover, outgoing students also expressed their belief that the Erasmus program would benefit their future academic careers. Likewise, Goldstein et al. (2019) underlined that by participating in overseas exchange programs, students in teacher training programs developed a belief in gaining "global citizenship" and taking part in exchange programs; they were always more involved in internationalization processes than other students.

Lastly, the Erasmus program's contribution to internationalization in teacher training programs was defined with two different coordinators' opinions. According to the first view, the Erasmus program does not contribute to teacher education's internationalization because definite standards for teacher education do not support the Erasmus program. Course compatibility is not ensured in most overseas universities, and not being enthusiastic about internationalizing teacher education and low level of English language skills also harms this situation. Inbar-Lourie and Donitsa-Schmidt (2013) underline that teacher candidates are not always supportive of internationalization efforts and are not keen to learn English. Correspondingly, some studies (Cantalini-Williams \& Tessaro, 2011; Trilokekar \& Kukar, 2011) specify that student teachers, who are engaging in an international teaching practicum, face language barriers stemming from challenges related to teaching non-English-speaking students.

Furthermore, Teichler (2004) stated that curricular integration is a problem within the Erasmus program in most institutions in Europe. In his research on the program, students take fewer classes abroad, and they report that 
about half the courses are not of a similar academic level as the program at home. Accordingly, course compatibility and curricular integration are obstacles to this issue.

According to the other view, however, the Erasmus program contributes to the internationalization of teacher education. This contribution is mostly not related to academic courses. It is generally about communication skills, initiative, empathy and tolerance, and adapting to different cultures. A coordinator involved in the study stated that these skills were more important for the teaching profession. We saw that the second view corresponded more to the views of outgoing and incoming students. Likewise, as stated in Zhao (2010); one of the most crucial aspects of globally-minded teacher education is to raise a "-responsive teacher," which means knowing what their students bring to school, the ability, and skills to interact with diverse learners and to form culturally responsive classrooms, instruction, and especially cultural sensitivity. Also, there are ideas in the literature that teacher candidates with overseas experience are more socially and culturally competent than candidates who lack such knowledge. For example, Mahon and Cushner (2002) determined that candidates who studied or participated in courses such as teaching practice abroad increased their intercultural and professional competencies and developed their self-efficacy skills. They made their own choices themselves abroad by facing new and different environments, and it also provided them with personal opportunities and intrinsic motivation. On the whole, Schneider (2004)'s analysis of 24 universities and colleges found that the "international" dimension was significantly lacking within their study programs. Additionally, when considering study programs for teachers concerning other study programs, it turned out that teacher education was the least internationalized (Vorkapic, 2016). In the globalizing world in the 21st century, there is a need for international education, intercultural competence, clinical experiences beyond borders, and globally available foreign language skills (Shaklee, 2012).

\subsection{Limitations of the Study}

The first limitation of our study is that our research sample is limited to three different regional universities in Turkey. Therefore, our sample may have been limited and unrepresentative of the whole picture. Although the study is qualitative research and its very nature, its aim is not generalization; future research may need to be conducted to gather data from a more significant sample with a quantitative way of analysis.

The second limitation is the data collection methods, the interview in this study. We acknowledge that case studies demand more than one data collection technique: observations, documents, or audiovisual artifacts. Consequently, data obtained in this study can be restricted by nature. Future research might extend beyond interviews to collect data and build on our work by engaging in observations and some other document analysis.

The third limitation is the selection of the participants. We must inform the readers that the number of student teachers who had the international experience within the Erasmus program is not too many in each institution (not exceeding ten students if we would guess the overall number). For this reason, our study is limited to only 12 interviews. Other studies should cover more participants in a longer timeline.

\subsection{Conclusion}

In conclusion, based on the findings of this study, we found that the Erasmus program's contribution to internationalization in teacher education was enabled to a large extent with the development of teacher candidates' social skills. Although social skills are essential in the teaching profession, teacher candidates must develop their academic competencies abroad. For this reason, the most crucial recommendation is that partnerships should be established with overseas universities that can foster teacher candidates academically. Moreover, student teachers should be given opportunities for practice or internships in teaching programs in the countries they visit.

The new insights that contribute to the academic field for this study are specified below:

- Internationalization efforts in teacher education are not sufficient in Turkey. We addressed the necessity to regulate the teacher education curricula, especially in-service teacher development in terms of international education.

- Turkish higher education systems (exclusively teacher education) should enhance course compatibility and curricular integration within the context of the Erasmus program.

- Student teachers should be motivated to take the experience of overseas teaching, internship opportunities, joint degree programs, or credit transfer in European and Non-European institutions.

- Engaging with diverse learners and tolerance toward multiculturalism is an urgently needed for teachers in today's world. The Erasmus program is a particular way of fostering these features. 
- Teacher education institutions should try covering academically advanced partners within the Erasmus program, and quality should be increased.

- Erasmus program commonly promotes social skills, communication abilities, socio-cultural compliance, and resilience to challenges more than academic qualities.

\section{Acknowledgments}

We hereby confirm that we have not received any grants or financial support from any bodies throughout the research process. It means there are no relevant competing interests to disclose. We thank all the participants who took their time off to appear in this study. Additionally, we are grateful for the insightful comments from the reviewers.

\section{References}

Abraham, G. Y., \& von Brömssen, K. (2018). Internationalisation in teacher education: Student teachers' reflections on experiences from a field study in South Africa. Education Inquiry, 9(4), 347-362. https://doi.org/10.1080/20004508.2018.1428035

Acedo, C. (2012). Internationalization of teacher education. Prospects, 42(1), 1-3. https://doi.org/10.1007/s11125-012-9225-y

Addleman, R, Nava, R. C., Cevallos, T., Brazo, C., J., \& Dixon, K. (2014). Preparing teacher candidates to serve students from diverse backgrounds: Triggering transformative learning through short-term cultural immersion. International Journal of Intercultural Relations, 43, 189-200. https://doi.org/10.1016/j.ijintrel.2014.08.005

Aktan, E., \& Sarı, B. (2010). An inquiry on application process of EU Erasmus Programme \& students' views regarding Erasmus programme of student exchange. European Perspectives on Internationalization, Exedra Special Issue, 239-268. Retrieved from http://exedra.esec.pt/docs/s-internacionalizacao/17-239-268.pdf

Altay, A. (2016). Influence of the Erasmus Student Mobility Programme on competence development of students (Unpublished master's thesis). Akdeniz University,

Altbach, P. G. (2004). Globalisation and the university: Myths and realities in an unequal world. Tertiary Education and Management, 10(1), 3-25. https://doi.org/10.1080/13583883.2004.9967114

Altbach, P. G., \& Knight, J. (2007). The internationalization of higher education: Motivations and realities. Journal of Studies in International Education, 11(3-4), 290-305. https://doi.org/10.1177/1028315307303542

Altbach, P. G., \& Teichler, U. (2001). Internationalization and exchanges in a globalized university. Journal of Studies in International Education, 5(1), 5-25. https://doi.org/10.1177/102831530151002

Altuğ, S. A., Sezgin, E. N., \& Önal, A. (2019). Does Erasmus+ programme improve the participants' intercultural communicative competence? SDU International Journal of Educational Studies, 6(1), 1-17. https://doi.org/10.33710/sduijes.537034

Anadolu University. (2021). Anadolu University ELT (UOLP-SUNY Cortland) Program Profile. Retrieved from https://www.anadolu.edu.tr/akademik/fakulteler/165/ingilizce-oguolp-suny-cortland/program-profili

Arslan, S. (2013). Perspectives of the Turkish participants on Erasmus exchange program. The Online Journal of Counseling and Education, 2(2), 9-18. Retrieved from https://www.idealonline.com.tr/IdealOnline/lookAtPublications/paperDetail.xhtml?uId=59509

Aslan Bağc1, Ö., Erdem, S., \& Erişen, Y. (2018). Evaluation of Erasmus+ KA103 mobility according to views of students and coordinators. Türkiye Eğitim Dergisi, 3(1), 54-76. Retrieved from https://dergipark.org.tr/tr/pub/turkegitimdergisi/issue/37897/426716

Aslan, B., \& Bayram Jacobs, D. (2014). Erasmus student mobility: Some good practices according to views of Ankara University exchange students. Journal of Education and Future, 5, 57-72. Retrieved from https://dergipark.org.tr/tr/pub/jef/issue/18637/196710

Atkinson, J. (2002). Four steps to analyse data from a case study method. Paper presented at Association for Information Systems (ACIS 2002 Proceedings), Australia. Retrieved from https://researchoutput.csu.edu.au/ws/portalfiles/portal/9635523

Aydarova, E., \& Marquardt, S. K. (2016). The global imperative for teacher education: Opportunities for comparative and international education. FIRE: Forum for International Research in Education, 3(1), 23-41. https://doi.org/10.18275/fire201603011066 
Barton, G. M., Hartwig, K. A., \& Cain, M. (2015). International students' experience of practicum in teacher education: An exploration through internationalisation and professional socialisation. Australian Journal of Teacher Education, 40(8), 149-163. https://doi.org/10.14221/ajte.2015v40n8.9

Bilici, N. (2016). A comparative analysis of the adaptation problems of the Erasmus program's international students in Turkey and Turkish Erasmus students in other countries. (Unpublished master's thesis). Haliç University, Istanbul.

Boyac1, A. (2011). Erasmus exchange students' comparative views on classroom management in Turkey and in their country (Anadolu University Case). Education and Science, 36(159), 270-282. Retrieved from http://egitimvebilim.ted.org.tr/index.php/EB/article/view/876

Brandenburg, U., Federkeil, G., Ermel, H., Fuchs, S., Groos, M., \& Menn, A. (2007). How to measure internationality and internationalisation of higher education institutions: Indicators and key figures (Vol. 22, Issue 92). CHE Centrum für Hochschulentwicklung.

Bryła, P. (2015). The impact of international student mobility on subsequent employment and professional career: A large-scale survey among polish former Erasmus students. Procedia - Social and Behavioral Sciences, 176, 633-641. https://doi.org/10.1016/j.sbspro.2015.01.521

Buchberger, F, Campos, B. P., Kallos D., \& Stephenson, J. (2000). Green paper on teacher education in Europe: High-quality education for high-quality education and training. Sweden: Umea. Retrieved from http://www.cep.edu.rs/sites/default/files/greenpaper.pdf

Cantalini-Williams, M., \& Tessaro, M. L. (2011). Teacher candidates' perceptions of an international practicum experience in Italian schools: Benefits of a short-term placement with faculty support. Canadian and International Education, 40(3), 45-60. Retrieved from https://ojs.lib.uwo.ca/index.php/cie-eci/article/download/9188/7374

Cardwell, P. J. (2020). Does studying abroad help academic achievement? European Journal of Higher Education, 10(2), 147-163. https://doi.org/10.1080/21568235.2019.1573695

Clarke, K. (2005). Critical multicultural education for remembering and reconciliation: A discussion of an interdisciplinary social science course for international students in Finland. Compare A Journal of Comparative Education, 35(4), 479-494. https://doi.org/10.1080/03057920500331447

CoHE. (1998). Teacher training programs for education faculties. Ankara: Turkish Council of Higher Education.

CoHE. (2007). Teacher training programs for education faculties. Ankara: Turkish Council of Higher Education.

CoHE. (2018). Teacher training programs for education faculties. Ankara: Turkish Council of Higher Education.

CoHE. (2020). Transfer of program renovation authority to the education faculties. Retrieved from https://www.yok.gov.tr/Sayfalar/Haberler/2020/egitim-fak\%C3\%BCltelerine-yetki-devri.aspx

Creswell, J. W. (2007). Qualitative inquiry and research designs: Choosing among five approaches (2nd Ed.). California: SAGE Publications.

Cushner, K. (2007). The role of experience in the making of internationally-minded teachers. Teacher Education Quarterly, Winter, 27-39. Retrieved from https://files.eric.ed.gov/fulltext/EJ795140.pdf

Çepni O., Aydın F., \& Kılınç A. Ç. (2018). The problems that students participating in Erasmus programme encountered and their solutions: A Phenomenological Study. Yüksekögretim ve Bilim Dergisi/Journal of Higher Education and Science, 8(3), 436-450. https://doi.org/10.5961/jhes.2018.285

Daekin, H. (2014) The drivers to Erasmus work placement mobility for UK students. Children's Geographies, 12(1), 25-39. https://doi.org/10.1080/14733285.2013.851063

Demir, A., \& Demir, S. (2009). The assessment of Erasmus program in terms of intercultural dialogue and interaction. The Journal of International Social Research, 2(9), 95-105. Retrieved from https://www.sosyalarastirmalar.com/articles/erasmus-programinin-kltrlerarasi-dyalog-ve-etklem-aisindan-de erlendrlmes-retmen-adaylariyla-ntel-br-alima-the-assesment-.pdf

Dinçer, S. (2014). Erasmus exchange program on cross-and multicultural education. The Matopolska School of Economics in Tarnów Research Papers Collection, 25(2), 63-69. Retrieved from http://cejsh.icm.edu.pl/cejsh/element/bwmeta1.element.desklight-d478fa33-f76d-470c-b645-15bd71898b9b

Dinçer, Ç., Aslan, B., \& Bayraktar, A. (2017). Ankara university Erasmus coordinators views on Erasmus programme Ankara Üniversitesi Eğitim Bilimleri Fakültesi Dergisi, 50(2), 201-223. 
https://doi.org/10.1501/egifak_0000001402

Dooly, M., \& Villanueva, M. (2006). Internationalisation as a key dimension to teacher education. European Journal of Teacher Education, 29(2), 223-240. https://doi.org/10.1080/02619760600617409

Duman, S. N. (2020). The Experiences of prospective teachers participating in Erasmus program. Kirlkkale Üniversitesi Sosyal Bilimler Dergisi, 10(2), 239-256. Retrieved from https://dergipark.org.tr/en/pub/kusbd/issue/56190/735991

Efeoglu, G. (2021). Effects of study abroad on pre-service English teachers' professional development. Journal of Narrative and Language Studies, 9(17), 243-256. Retrieved from https://www.nalans.com/index.php/nalans/article/view/388

Elmalı, G. G. (2013). Evaluation of the implementation of the European Union Education and Youth Programmes in Turkey in the context of Erasmus Programme (Unpublished master's thesis). Afyon Kocatepe University, Afyonkarahisar.

Eret-Orhan, E., Ok, A., \& Capa-Aydin, Y. (2017). We train, but what do they think? Pre-service teachers' perceptions of the adequacy of their teacher education in Turkey. Asia-Pacific Journal of Teacher Education, 46(2), 183-198. https://doi.org/10.1080/1359866X.2017.1355050

Ersoy, A. (2013). Turkish teacher candidates' challenges regarding cross-cultural experiences: The case of Erasmus Exchange Program. Education and Science, 38(168), 154-166. Retrieved from http://egitimvebilim.ted.org.tr/index.php/EB/article/view/1287

European Commission. (2014). The Erasmus impact study: Effects of mobility on the skills and employability of students and the internationalization of higher education institutions. Luxembourg: Publications Office of the European Union. Retrieved from https://ec.europa.eu/assets/eac/education/library/study/2014/erasmus-impact-summary_en.pdf

European Commission. (2018a). Erasmus+ 2018 in numbers: Turkey. Retrieved from https://ec.europa.eu/programmes/erasmus-plus/sites/default/files/erasmusplus-factsheet-tr_en.pdf

European Commission. (2018b). The Erasmus impact study regional analysis. A comparative analysis of the effects of Erasmus on the personality, skills and career of students of European regions and selected countries. Luxembourg: Publications Office of the European Union. Retrieved from https://op.europa.eu/en/publication-detail/-/publication/46bd1ebb-b2db-11e6-9e3c-01aa75ed71a1

European Commission. (2022). Erasmus+ programme guide. Retrieved from https://erasmus-plus.ec.europa.eu/programme-guide/erasmusplus-programme-guide

European Parliamentary Research Service. (2018). Erasmus 2020-2027: The union programme for education, training, youth and support. Briefing: EU Legislation in Progress. Retrieved from https://www.europarl.europa.eu/RegData/etudes/BRIE/2018/628313/EPRS_BRI(2018)628313_EN.pdf

Feyen, B., \& Krzaklewska, E. (2013). The Erasmus programme and the "Generation Erasmus"-A short overview. In B. Feyen \& E. Krzaklewska (Eds.), The Erasmus Phenomenon-Symbol of a New European Generation? (pp. 9-17). Frankfurt: Peter Lang Edition. https://doi.org/10.3726/978-3-653-03007-5

Furka, I., \& Johnsen, B. (2017). The effect of short-term Erasmus+ teacher training courses on foreign language teachers' personal and professional competences-The case of four teachers. WoPaLP, 11, 46-59. Retrieved from http://langped.elte.hu/WoPaLParticles/W11Furka-Johnsen.pdf

Garii, B. (2008). Beginning careers in international settings: Impacts on continued classroom practice. American Educational Research Association Annual Meeting, New York, NY.

Goldstein, O., Natur, N., Trahar, S., \& Yemini, M. (2019). Students shaping internationalization in a conflict-ridden society: Experiences of Israeli teacher education colleges. Journal of Studies in International Education, 23(1), 66-83. https://doi.org/10.1177/1028315318803711

Goodwin, A. L. (2010). Globalization and the preparation of quality teachers: Rethinking knowledge domains for teaching. Teaching Education, 21(1), 19-32. https://doi.org/10.1080/10476210903466901

Gökten, Ö., \& Emil, S. (2019). Exploring the effect of Erasmus program on cultural intelligence of university students. Hacettepe University Journal of Education, 34(3), 769-785. https://doi.org/10.16986/HUJE.2018045609

Guba, E. G., \& Lincoln, Y. S. (1982). Epistemological and methodological bases of naturalistic inquiry. ECTJ, 
30(4), 233-252. https://doi.org/10.1007/BF02765185

Harper, H., \& Dunkerly, J. (2013). Educating the world: Teachers and their work as defined by the United Nations Educational, Scientific and Cultural Organization (UNESCO). In Y. Hebert \& A. A. Abdi (Eds.), Critical Perspectives on International Education (pp. 279-291). Sense Publishers. https://doi.org/10.1007/978-94-6091-906-0_20

Inbar-Lourie, O., \& Donitsa-Schmidt, S. (2013). Englishization in an Israeli teacher education college: Taking the first steps. In A. Doiz, D. Lasagabaster \& J. M. Sierra (Eds.), English-medium instruction at universities: Global challenges (pp. 151-162). Toronto, ON: Multilingual Matters. https://doi.org/10.21832/9781847698162-012

Jacobone, V., \& Moro, G. (2015). Evaluating the impact of the Erasmus programme: Skills and European identity. Assessment and Evaluation in Higher Education, 40(2), 309-328. https://doi.org/10.1080/02602938.2014.909005

Kabilan, M. K. (2013). A phenomenological study of an international teaching practicum Pre-service teachers' professional development experiences. Teaching and Teacher Education, 36, 198-209. https://doi.org/10.1016/j.tate.2013.07.013

Kagnic1, S. (2016). The impact of EU Mobility Programmes on the construction of European identity: A study on Turkish Erasmus Students (Unpublished master's thesis). Yaşar University, İzmir.

Kasapoğlu Önder, R., \& Balci, A. (2010). Erasmus öğrenci öğrenim hareketliliği programının 2007 yılında programdan yararlanan Türk öğrenciler üzerindeki etkileri. Ankara Avrupa Çalışmaları Dergisi, 9(2), 93-116. https://doi.org/10.1501/Avraras_0000000150

Kehm, B. M. (2005). The contribution of international student mobility to human development and global understanding. Online Submission, 2(1), 18-24.

Kırkgöz, Y. (2016). Integrating study abroad in teacher education: Enhancing the curriculum. In D. M. Velliaris \& D. Coleman-George (Eds.), Handbook of Research on Study Abroad Programs and Outbound Mobility (pp. 177-197). IGI Global. https://doi.org/10.4018/978-1-5225-0169-5.ch024

King, R., \& Ruiz-Gelices, E. (2003). International student migration and the European "Year Abroad": Effects on European identity and subsequent migration behaviour. International Journal of Population Geography, 9(3), 229-252. https://doi.org/10.1002/ijpg.280

Kissock, C., \& Richardson, P. (2010). Calling for action within the teaching profession: It is time to internationalize teacher education. Teaching Education, 21(1), 89-101. https://doi.org/10.1080/10476210903467008

Knight, J. (2004). Internationalization Remodeled: Definition, approaches, and rationales. Journal of Studies in International Education, 8(1), 5-31. https://doi.org/10.1177/1028315303260832

Knight, J. (2012). Student mobility and internationalization: Trends and tribulations. Research in Comparative and International Education, 7(1), 20-33. https://doi.org/10.2304/rcie.2012.7.1.20

Kondakç1, Y. (2003). A new vision for higher education in Europe. Education and Science, 28(129), 74-82. Retrieved from http://egitimvebilim.ted.org.tr/index.php/EB/article/view/5116/1199

Larsen, M. A. (2016). Globalisation and internationalisation of teacher education: A comparative case study of Canada and Greater China. Teaching Education, 27(4), 396-409. https://doi.org/10.1080/10476210.2016.1163331

Leutwyler, B., Popov, N., \& Wolhuter, C. (2017). The Internationalization of Teacher Education: Different Contexts, Similar Challenges. BCES Conference Books, 15, 66-78. https://doaj.org/article/c2aaecedb03242139ac661c4cdb3100b

Llurda, E., Gallego-Balsà, L., Barahona, C., \& Martin-Rubió, X. (2016). Erasmus student mobility and the construction of European citizenship. Language Learning Journal, 44(3), 323-346. https://doi.org/10.1080/09571736.2016.1210911

Mahon, J., \& Cushner, K. (2002). The overseas student teaching experience: Creating optimal culture learning. Multicultural Perspectives, 4(3), 3-8. https://doi.org/10.1207/s15327892mcp0403_2

Mahon, J. (2010). Fact or fiction? Analyzing institutional barriers and individual responsibility to advance the internationalization of teacher education. Teaching Education, 21(1), 7-18. 
https://doi.org/10.1080/10476210903466893

Maiworm, F. (2001). ERASMUS: Continuity and change in the 1990s. European Journal of Education, 36(4), 459-472. https://doi.org/10.1111/1467-3435.00082

Maiworm, F., \& Teichler, U. (2002). The students' experience. In U. Teichler (Ed.), ERASMUS in the SOCRATES Programme: Findings of an Evaluation Study (pp. 83-116). Bonn: Lemmens.

Marginson, S., \& van der Wende, M. (2009). Europeanisation, international rankings and faculty mobility: Three cases in higher education globalisation. Higher education to 2030 Volume 2: Globalisation. OECD. pp. 109-144. https://doi.org/10.1787/9789264075375-6-en

Mazeikiene, N., \& Loher, D. (2008). Competence of university teachers and graduate students for international cooperation: Teachers' intercultural competence in mobility programmes. Socialiniai Mokslai, 60(2), 48-65. Retrieved from https://etalpykla.lituanistikadb.lt/object/LT-LDB-0001:J.04 2008 1367165184548/J.04 20 08 1367165184548.pdf

METU. (2021). Middle East Technical University and the State University of New York, English language teaching program profile. Retrieved from https://suny.metu.edu.tr/ingilizce-ogretmenligi-tefl

Miles, M. B., \& Huberman, A. M. (1994). Qualitative data analysis (2nd ed.). Sage, Thousand Oaks.

Ministry of European Affairs. (2018). Erasmus+ Key Action 1: Learning mobility of individuals, Mobility of students and staff in higher education between programme countries, Handbook for higher education institutions. Ankara: Turkish National Agency. Retrieved from https://www.ua.gov.tr/anasayfa/icerikler/baglanti-ve-dokumanlar/2018-donemi-ka103-sozlesme-belgeleri/

Mizikaci, F., \& Arslan, Z. U. (2019). A European perspective in academic mobility: A case of Erasmus program. Journal of International Students, 9(2), 705-726. https://doi.org/10.32674/jis.v9i2.1138

MoNE. (2011). The basic law of the Ministry of National Education (MoNE). Retrieved from https://www.mevzuat.gov.tr/MevzuatMetin/1.5.1739.pdf

MoNE. (2017). The guidelines regarding the teaching practice in the schools affiliated to the Ministry of National Education. Retrieved from http://mevzuat.meb.gov.tr/dosyalar/1961.pdf

Mutlu, S., Alacahan, O., \& Erdil, M. (2010). Comparison of the personal and cultural change taking place between EU Erasmus students and Turkish Erasmus students (within the sample of Adam Mickiewicz University in the city of Poznan, Poland). Eurasian Journal of Anthropology, 1(1), 33-43.

Mutlu, S. (2020). Development of European consciousness in Erasmus students. The Journal of Education Culture and Society, 2, 87-102. https://doi.org/10.15503/jecs20112.87.102

Nazeer-Ikeda, R. Z. (2014). Reforming teacher education through localization-internationalization: Analyzing the imperatives in Singapore. International Perspectives on Education and Society, 25, 169-200. https://doi.org/10.1108/S1479-367920140000025014

Njie, B. \& Asimiran, S. (2014). Case study as a choice in qualitative methodology. IOSR Journal of Research \& Method in Education (IOSR-JRME), 4(3), 35-40. https://doi.org/10.9790/7388-04313540

Olmos, L. E., \& Torres, C. A. (2009). Theories of the State, Educational Expansion, Development, and Globalizations: Marxian and Critical Approaches. In R. Cowen \& A. M. Kazamias (Eds.), International Handbook of Comparative Education (Vol. 22, pp. 73-86). Springer. https://doi.org/10.1007/978-1-4020-6403-6_6

Özdem, G. (2013). Evaluation of Erasmus Program in higher education institutions (Example of Giresun University). Educational Administration: Theory and Practice, 19(1), 61-98. Retrieved from https://dergipark.org.tr/tr/download/article-file/108160

Papatsiba, V. (2006). Making higher education more European through student mobility? Revisiting EU initiatives in the context of the Bologna Process. Comparative Education, 42(1), 93-111. https://doi.org/10.1080/03050060500515785

Quezada, R. L. (2010). Internationalization of teacher education: Creating global competent teachers and teacher educators for the twenty-first century. Teaching Education, 21(1), 1-5. https://doi.org/10.1080/10476210903466885

Raikou, N., \& Karalis, T. (2010). Non-formal and informal education processes of European lifelong learning programmes for higher education: The case of the Erasmus programme in a Greek Peripheral University. 
International Journal of Interdisciplinary Social Sciences, 1(5), 103-114. https://doi.org/10.18848/1833-1882/CGP/v05i01/53064

Schneider, A. I. (2004). What can be done to internationalize teacher training? A research report on the undergraduate training of secondary school teachers. International Studies Perspectives, 5, 316-320. https://doi.org/10.1111/j.1528-3577.2004.00176.x

Scott, P. (2009). The internationalization of higher education and research: Purposes and drivers. In Gaebel, L. Perser, B. Wachter \& L. Wilson (Eds.), Internationalization of European Higher Education. An EUA/ACA Handbook (Vol.3, pp. 24). Berlin: Raabe.

Selvitopu, A. (2015). Internationalization in higher education. In A. Aypay (Eds.), Higher education area, context and policies in Turkey (pp. 281-308). Ankara: Pegem Publishing.

Seyhan Yücel, M. (2013). Language and cultural experiences of German language pre-service teachers within Erasmus Programme. Journal of Faculty of Educational Sciences, 46(1), 23-47. https://doi.org/10.1501/Egifak_0000001272

Shaklee, B. D. (2012). Concluding thoughts: Developing opportunities to internationalize teacher education. In B. Shaklee \& S. Baily (Eds.), Internationalization Teacher Education in the United States (pp. 237-249). Rowman \& Littlefield Publishers.

Shaklee, B. D., \& Baily, S. (2012). Introduction: A framework for internationalizing teacher preparation. In B. D. Shaklee \& S. Baily (Eds.), Internationalizing Teacher Education in the United States (pp. 1-10). Rowman \& Littlefield Publishers.

Sharma, S. (2014). Internationalizing teacher education through study abroad: Crossing borders, building bridges, and raising consciousness toward social justice. In S. Sharma, J. Phillon, R. Rahatzad \& H. Sasser (Eds.), Internationalizing Teacher Education for Social Justice: Theory, Research and Practice (pp. 179-192). International Age Publishing.

Shonia, O. N., \& Stachowski, L. L. (2014). Standing the test of time: Overseas student teaching's lasting impact on participants' perspectives and practices. In S. Sharma, J. Phillion, J. Rahatzad \& H. L. Sasser (Eds.), Internationalizing Teacher Education for Social Justice: Theory, Research, and Practice (pp. 57-76). Information Age Publishing.

Sieber, P., \& Mantel, C. (2012). The internationalization of teacher education: An introduction. Prospects, 42(1), 5-17. https://doi.org/10.1007/s11125-012-9218-x

Sigalas, E. (2009). Does ERASMUS student mobility promote a European identity? Web papers on Constitutionalism \& Governance beyond the State, 2, 1-24.

Sigalas, E. (2010). The role of personal benefits in public support for the EU: Learning from the Erasmus students. West European Politics, 33(6), 1341-1361. https://doi.org/10.1080/01402382.2010.508912

Smolcic, E., \& Katunich, J. (2016). Teachers crossing borders: A review of the research into cultural immersion field experience for teachers. Teaching and Teacher Education, 62, 47-59.

https://doi.org/10.1016/j.tate.2016.11.002

Souto-Otero, M., Huisman, J., Beerkens, M., de Wit, H., \& Vujic, S. Č. (2013). Barriers to international student mobility: Evidence from the Erasmus program. Educational Researcher, 42(2), 70-77. https://doi.org/10.3102/0013189X12466696

Spiro, J. (2011). Guided interaction as intercultural learning: Designing internationalisation into a mixed delivery teacher education programme. Higher Education Research and Development, 30(5), 635-646. https://doi.org/10.1080/07294360.2011.598453

Stachowski, L. L., \& Sparks, T. (2007). Thirty years and 2,000 student teachers later: An overseas student teaching project that is popular, successful, and replicable. Teacher Education Quarterly, 34(1), 115-132.

Szymanska, E. (2014). The benefits and problems ensuing from the internationalisation of universities from the point of view of students and academic teachers participating in the Erasmus programme. Ekonomia $i$ Prawo, 13(1), 37. https://doi.org/10.12775/eip.2014.003

Teachers for EFA. (2011). Concept Note: Third International Policy Dialogue Forum, 13-14 September 2011, Bali, Indonesia. Paris: International Task Force on Teachers for EFA. Retrieved from http://www.teachersforefa.unesco.org/Resources/All/Concept\%20note_Bali_9\%20Sept.pdf. 
Teichler, U. (2004). Temporary study abroad: The life of ERASMUS students. European Journal of Education, 39(4), 395-408. https://doi.org/10.1111/j.1465-3435.2004.00193.x

Teichler, U., \& Janson, K. (2007). The professional value of temporary study in another European country: Employment and work of former ERASMUS students. Journal of Studies in International Education, 11(3-4), 486-495. https://doi.org/10.1177/1028315307303230

Tekin, U., \& Hiç Gencer, A. (2013). Effects of the Erasmus Programme on Turkish universities and university students. Trakya Üniversitesi Sosyal Bilimler Dergisi, 15(1), 109-122. Retrieved from https://dergipark.org.tr/tr/download/article-file/321453

Townsend, T., \& Bates, R. (2007). Teacher education in a new millennium: Pressures and possibilities. In T. Townsend \& R. Bates (Eds.), Handbook of Teacher Education (pp. 3-22). Springer Netherlands. https://doi.org/10.1007/1-4020-4773-8_1

Trilokekar, R. D., \& Kukar, P. (2011). Disorienting experiences during study abroad: Reflections of pre-service teacher candidates. Teaching and Teacher Education, 27, 1141-1150. https://doi.org/10.1016/j.tate.2011.06.002

Turkish National Agency. (2009). The lifelong learning programme (LLP) in Turkey: Impact assessment report.

Unlu, I. (2015). Teacher candidates' opinions on Erasmus student exchange program. Kuram ve Uygulamada Egitim Bilimleri, 15(1), 23-237. https://doi.org/10.12738/estp.2015.1.2176

Ünal, M. (2011). The evaluation of European Union Erasmus Student Mobility Programme in the framework of CIPP (context, input, process, product) evaluation model (Unpublished doctoral dissertation). Gazi University, Institute of Educational Sciences, Ankara.

Vorkapic, S. T. (2016). Promotion of internationalization of teacher education: A case study from Croatia. In D. M. Velliari \& D. Coleman-George (Eds.), Handbook of Research on Study Abroad Programs and Outbound Mobility (pp. 651-671). IGI Global. https://doi.org/10.4018/978-1-5225-0169-5.ch026

Walters, L. M., Garii, B., \& Walters, T. (2009). Learning globally, teaching locally: Incorporating international exchange and intercultural learning into pre-service teacher training. Intercultural Education, 20(1), 151-158. https://doi.org/10.1080/14675980903371050

Weidman, J. C., Jacob, W. J., \& Casebeer, D. (2014). Conceptualizing teacher education in comparative and international context. In A. W. Wiseman \& E. Anderson (Eds.), Annual Review of Comparative and International Education 2014 (pp. 115-145). Bristol, UK: Emerald. https://doi.org/10.1108/S1479-367920140000025012

White, C. (2016). Internationalizing teacher education: A U.S. - Vietnam case study. International Journal of Education and Practice, 4(3), 117-126. https://doi.org/10.18488/journal.61/2016.4.3/61.3.117.126

Yin, R. K. (2014). Case study research: Design and methods (5th ed.). CA: SAGE Publications.

Youthnetworks. (2021). Turkey joined Erasmus plus programme 2021-2027. Retrieved from https://youthnetworks.net/turkey-joined-the-erasmus-plus-programme-2021-2027/

Yücel, M. S. (2013). Language and cultural experiences of German language pre-service teachers within ERASMUS programme. Ankara Üniversitesi Ĕ̈itim Bilimleri Fakültesi Dergisi, 46(1), 23-47. https://doi.org/10.1501/Egifak_0000001272

Yücelsin-Taş, Y. T. (2013). Problems of the Erasmus programme and their solutions. Turkish Studies, 8(10), 763-770. https://doi.org/10.7827/TurkishStudies.5938

Zeichner, K. (2010). Rethinking the connections between campus courses and field experiences in college- and university-based teacher education. Journal of Teacher Education, 61(1-2), 89-99. https://doi.org/10.1177/0022487109347671

Zhao, Y. (2010). Preparing globally competent teachers: A new imperative for teacher education. Journal of Teacher Education, 61(5), 422-431. https://doi.org/10.1177/0022487110375802

\section{Copyrights}

Copyright for this article is retained by the author(s), with first publication rights granted to the journal.

This is an open-access article distributed under the terms and conditions of the Creative Commons Attribution license (http://creativecommons.org/licenses/by/4.0/). 